\title{
Failure mechanism and stability analysis of bank slope deformation under the synergistic effect of heavy rainfall and blasting vibration
}

\section{Chenyang Ma}

China University of Geosciences

\section{LiWu (DIwu@cug.edu.cn)}

China University of Geosciences https://orcid.org/0000-0001-9651-3772

\section{Miao Sun}

China University of Geosciences

Dexing Lei

China University of Geosciences

\section{Research Article}

Keywords: bank slope, synergistic effect, rainfall, underwater blasting, vibration

Posted Date: March 10th, 2021

DOI: https://doi.org/10.21203/rs.3.rs-261053/v1

License: (c) (i) This work is licensed under a Creative Commons Attribution 4.0 International License. Read Full License

Version of Record: A version of this preprint was published at Geotechnical and Geological Engineering on June 8th, 2021. See the published version at https://doi.org/10.1007/s10706-021-01868-y. 


\section{Abstract}

Underwater drilling blasting technique is often adopted to clear away the obstructed reef and dredge-cut in the mountainous waterway dredging engineering. However, the vibration of the underwater blasting and excavation of the riverbed has a certain influence on the stability of bank slopes. Combined with the partial bank collapse phenomenon in the waterway regulation project between two dams in the Three Gorges reservoir area, the change of pore water pressure of unsaturated soil under heavy rainfall and the increase of permanent displacement of soil under blasting vibration in the reservoir area are discussed. This paper explains the weakening effect of rainfall infiltration and blasting vibration on the stability of the bank slope. By studying the law of slope failure deformation under the separate action and coupling action, it is found that rainfall infiltration promotes the increase of slope permanent displacement and the blasting vibration enlarges the infiltration area of the soil, which demonstrated the accelerated failure mechanism of the rainfall-blasting slope.

\section{Introduction}

With the vigorous development of inland waterway construction in China, underwater reef blasting engineering presents a trend of large volume, large dosage and long period. However, underwater drilling and blasting will have adverse effects on the surrounding environment. When there is a potential landslide in the reef blasting area and heavy rainfall occurs within the construction period, underwater drilling blasting can easily induce a landslide which poses a great threat to the stability of the reservoir bank.

Scholars around the word have done a lot of work on the evaluation of slope stability in the Three Gorges area (Tang et al. 2019). Many common reservoir landslides are caused by factors such as seasonal rainfall (Li et al. 2010; Wu et al. 2010) and changing reservoir water levels (Yin et al. 2016). The frequent microseismic events after the Three Gorges Dam impoundment are also one of the key factors leading to the dynamic instability of the slope bank (Li et al. 2016; Yang et al. 2020). Hence, when studying the bank slope stability of the reservoir, the coupling effect of multiple factors should be established simultaneously to avoid the analysis from a single aspect.

In traditional analysis of mine slope induced by the blasting vibration, the studies of dynamic response mainly involved in different conditions, but not enough in the impact of rainfall infiltration and underwater blasting (Wu et al. 2020; Jiang et al. 2018). In analysis of the slope stability induced by the rainfall, the rainfall characteristics (quantity, intensity and distribution) (Tang et al. 2015; Liu et al. 2018) and reservoir water level fluctuation (Hu et al. 2012; Yang et al. 2017; Zhao et al. 2017.) are considered more, while the disturbing factors of underwater blasting excavation is considered less (Miao et al. 2018; Tang et al. 2015; Li et al. 2018). With high intensification of human activities, landslides in mining and bank region have occurred frequently in recent years (Xu and Huang 2013; Yin 2013; Ma and Hu 2016). Blasting induced seismic waves as well as heavy rainfall have a damage effect on high-steep slopes or excavation surfaces, especially in joint fissure development and an important effect on rock slope 
stability (Li et al. 2006; Mikos et al. 2004; Panek et al. 2011). Both rainfall infiltration and blasting vibration degradation will weaken the strength of rock and soil mass (Ma et al. 2018; Song et al. 2016). However, there are still few studies on the effects of rainfall and blasting. So, it's an urgent problem in the geotechnical field to study the catastrophic model and stability analysis of bank slope under the synergistic effect of heavy rainfall and blasting in waterway dredging engineering.

Based on the investigation and numerical simulation of local bank collapse points in the dredged area of the waterway, the stability of bank slope and failure modes of bank collapse were analyzed in this paper, which can provide a theoretical basis for the protection designing of bank collapse and control technology of underwater drilling blasting in the heavy rainfall period.

\section{Slope Geological Environmental Conditions 2.1 Engineering geological conditions.}

The study area is located at $14.8 \mathrm{~km}$ downstream of the Three Gorges dam site, as shown in Fig. 1, which is cut by the Yangtze River. The topography along the bank of Shaijingping is changeable. Owing to the Three Gorges special highway and provincial S334 road construction, the phenomenon of the slope artificially reconstructed is obvious. The soil of the bank slope is mixed with a lot of artificial masonries retaining wall roadbed. The bank slope presents the "finger-like" landform between ridges and valleys. The outcrops in this region are Sinian crystalline granite and quaternary artificial deposits. There are no large fault zones. Small faults are not well developed, too. The seismic intensity is VI degree. The seasonal gullies on the ground surface are well developed in the region. The groundwater level changes obviously with rainfall and drains to the low-lying belt such as the Yangtze River nearby or supplies the weathering fissure water of the crystalline rock below. According to the investigation in 2017, the slope of this section was completely cut off due to bank collapse, which hindered the traffic and waterway operation.

\subsection{Features of local bank collapse points.}

Affected by the water soaking, wave erosion, rainfall, and the effects of dredging and blasting works, in the middle part of the reef blast point LT7, the steep soil slope bank collapsed and deformed. The collapsed point is $40 \sim 50 \mathrm{~m}$ away from the S334 and S58 Expressway as the crow files and its plane morphology is lingual. The main collapse direction is $205^{\circ}$. The vertical length is more than $15 \mathrm{~m}$. The bank caving width is $10 \sim 15 \mathrm{~m}$ and the area is about $45 \mathrm{~m}^{2}$. The thickness is $3.0 \sim 5.0 \mathrm{~m}$ and the volume is about $180 \mathrm{~m}^{3}$. The upper layer of the collapsed section has a loose structure of artificial backfill rock and sand. The mechanic strength of the underlying fully-strongly weathered granite is low and its resistance to erosion and denudation is poor. The water sensitivity of upper and lower soil mass is strong. The inhomogeneous binary structure of the granite under the special surface deep overburden provides the material and space conditions for the bank collapse. 


\section{Simulation Analysis Of Slope Stability \\ 3.1 Model and material properties}

According to the survey data and geological engineering profile of the bank collapse area (Fig. 2), a typical section B-B' was selected, as shown in Fig. 3. The slope generalization simulation model was established by Geo-studio software and the geometric dimensions are shown in Fig. 4.

The main rock and soil mechanical parameters shown in Table 1 and Fig. 4 are synthetically determined on the premise of engineering geomechanical analysis (Kiran et al.2016.) and by comparing the rock and soil mass test parameters with the same geological conditions in adjacent areas (Zheng et al.2010; Liu et al.2005). In the table, $y$ is the unit weight, $E$ is elasticity modulus, $v$ is poisson ratio, $S r$ is saturability, $c$ is cohension, $\varphi$ is internal friction angle, $K_{\text {sat }}$ is saturation permeability coefficient.

Table 1

Hydrological and physical mechanical parameters of the bank slop materials

\begin{tabular}{|llllllll|}
\hline Geotechnical units & $V\left(\mathrm{kN} / \mathrm{m}^{3}\right)$ & $E(\mathrm{kPa})$ & $\boldsymbol{V}$ & $\mathcal{S r}$ & $K_{\text {sat }}(\mathrm{m} / \mathrm{s})$ & \multicolumn{2}{c|}{ Shear strength } \\
\hline Backfill soil & & & & & & $\boldsymbol{c}(\mathrm{kPa})$ & $\boldsymbol{\varphi}\left({ }^{\circ}\right)$ \\
\hline Strongly weathered granite & 19.7 & $5.64 \times 10^{6}$ & 0.26 & 0.4 & $7.2 \times 10^{-7}$ & 120 & 35 \\
\hline Granite bedrock & 24.5 & $1.09 \times 10^{8}$ & 0.2 & & & 1000 & 52 \\
\hline
\end{tabular}

\subsection{Rainfall and blasting boundaries}

According to Yichang weather station's more than 20 years of statistics, the average annual rainfall was $1192.70 \mathrm{~mm}$ and 70 percent of the annual rainfall was concentrated in June $\sim$ August. Figure 5 shows the histogram of rainfall in Yichang from 8 June to 8 July, which was the heaviest rainfall season in history. At the same time, on 27 Jun, the 24-hour rainfall of $235 \mathrm{~mm}$ was the largest daily precipitation in the past 30 years. Therefore, the precipitation data measured from 27 Jun to 2 July in this area were selected for analysis. Based on the monitoring data, the designed rainfall intensity is $60 \mathrm{~mm} / \mathrm{d}$, and last for six days in the SEEP/W module. The left side and bottom of the slope are set as impervious boundaries. The top and slope are rainfall infiltration boundaries. The water head boundary at the front edge of the slopes is determined according to the reservoir water level, and the stable groundwater at the stable groundwater at the back edge is the constant water head boundary.

A large number of seismic damages shows that horizontal seismic action is the main cause of slope failure. Hence, the field blasting vibration data were collected. Figure 6 shows the time-history curve of 
blasting seismic waves in the horizontal direction and was applied for the QUAKE/W module. In the Quake/w module, a fixed constraint is applied around the bedrock, and the time-history analysis method is adopted after the horizontal blasting vibration accelerate curve is input. So that, the dynamic response of each point of the slope under blasting vibration can be obtained.

\subsection{Working condition and evaluation}

According to the location conditions of the reservoir bank, the maximum variation of water level in this area is within $10 \mathrm{~m}$, and the most likely factors leading to deformation and failure of the bank slope are rainfall and construction vibration.

Evaluation of bank slopes stability was based on the technical requirements for the design of geological disaster prevention project in the Three Gorges Reservoir area and earthquake landslide risk assessment, as shown in Table 2 (Wu et al. 2018).

Table 2

Standard table for slope stability evaluation

\begin{tabular}{|llll|}
\hline \multicolumn{2}{|l}{ Rainfall evaluation criterion } & \multicolumn{2}{l|}{ Blast evaluation criterion } \\
\hline Coefficient of stability & Steady state & Permanent displacement & Hazard rating \\
\hline$F_{\mathrm{s}}<1.00$ & instability & $0 \sim 0.1$ & Low risk \\
\hline $1.00<F_{\mathrm{s}} \leq 1.05$ & Understable & $0.1 \sim 0.5 \mathrm{~cm}$ & Medium risk \\
\hline $1.05<F_{\mathrm{s}} \leq \mathrm{F}_{\mathrm{st}}$ & Basically stable & $0.5 \sim 2.0 \mathrm{~cm}$ & High risk \\
$F_{\mathrm{s}} \geq F_{\mathrm{st}}$ & stable & $\geq 2 \mathrm{~cm}$ & Extreme risk \\
\hline Annotation: $F_{\mathrm{st}}$ is the factor of safety of slope with different hazard levels and working condition \\
\hline
\end{tabular}

\section{Numerical Analysis}

\subsection{Slope stability under the effect of rainfall}

Infiltration of rainfall can change the saturation of the soil and the pore water pressure. The pore water pressure at different positions on the slope has been monitored and found to gradually increased as the rainfall continues. As seen in Fig. 7, the pore water pressure between $80 \mathrm{~m} \sim 90 \mathrm{~m}$ elevation increases sharply at the beginning of rainfall. After the rainfall began 1 hour, it increased sharply from $-195 \mathrm{kPa}$ to $-125 \mathrm{kPa}$. With the continuous rainfall, the growth rate of pore water pressure gradually slows down and finally reached $-50 \mathrm{kPa}$. In the range of $70 \mathrm{~m} \sim 80 \mathrm{~m}$ elevation, the pore water pressure is not significant with the continuous change of rainfall. Therefore, the effect of rainfall infiltration decreases gradually from the surface of the slope to the depth of the slope with continuous rainfall. Figure 8 shows the 
variation trend of pore water pressure at the bottom of the slope in $60 \mathrm{~m} \sim 70 \mathrm{~m}$ elevation. The pore water pressure at the bottom of the slope has an approximately linear relationship.

The pore water pressure of the $65 \mathrm{~m}$ original characteristic water level finally reached $50 \mathrm{kPa}$ at the end of rainfall, which suggested that the water level rose and the soil gradually changed from unsaturated state to saturated state.

In the process of rainfall infiltration, the increased pore water pressure of soil leads to the decrease of matric suction of soil mass, which is finally reflected in the weakening soil strength and safety factor. It can be seen from Fig. 9 that the slope safety factor decreases continuously with the continuous rainfall, from 1.136 to 1.016 . When the rainfall ended, the safety factor will continue to fall to some extent, but not by much, about $6 \%$. That means the minimum safety factor is not the end of the rainfall period, there is a certain lag phenomenon. According to the Table 2, it can be inferred that the bank slope is in an understable state.

\subsection{Slope stability under blasting action}

As shown in Fig. 10, under the blast load, the instantaneous instability of the slope does not necessarily lead to direct failure of the slope. The safety factor of slope fluctuates with different vibration time. The safety factor of the slope at the beginning of blasting is 1.136. After the blasting, the safety factor is reduced to 1.076. The horizontal displacement of the slope top monitor point which was marked in Fig. 3 , was analyzed. At $0.602 \mathrm{~s}$, the slope safety factor reaches the minimum value of 0.614 , but the slope displacement value at the corresponding time does not reach the maximum value. Therefore, the Newmark method is needed to further calculate the permanent displacement and evaluate the bank slope stability under blasting vibration (Wang et al. 2013). From Fig. 11, it can be found that the change of permanent displacement in the early stage of blasting vibration is not obvious. After the $0.4 \mathrm{~s}$, the permanent displacement surges to $0.12 \mathrm{~cm}$ with the rapid change of acceleration, which is a mediumdangerous landslide.

\subsection{Safety and stability of slope under the combined action of rainfall and blasting}

Rainfall typically lasts for hours or even days, while an explosion typically occurs within seconds. In order to explore the stability of slope under the action of blasting vibration and heavy rainfall, blasting seismic waves were applied at different rainfall duration points $(1 \mathrm{~h}, 1 \mathrm{~d}, 3 \mathrm{~d}, 6 \mathrm{~d})$ to observe the slope changes as shown in Fig. 12.

When there is no rainfall in the early stage, the permanent displacement of the slope under blasting vibration is only $0.12 \mathrm{~cm}$. After $1 \mathrm{~h}$ of rainfall, the blasting vibration load was applied and the permanent displacement of the slope reached $1.24 \mathrm{~cm}$. It reflects that the rainfall infiltration intensifies the blasting vibration to the failure of the slope. When the blasting load is applied after the duration of rainfall $1 \mathrm{~d}, 3 \mathrm{~d}$ and $6 \mathrm{~d}$, the permanent displacement of the slope is respectively $2.7 \mathrm{~cm}, 3.56 \mathrm{~cm}$ and $12.9 \mathrm{~cm}$. That is to say, the longer the duration of rainfall in the early stage, the greater the permanent displacement of slope 


\section{Failure Mechanism Of Bank Slope Deformation Under Rainfall- blasting Action}

\subsection{Rainfall infiltration stage}

Rainfall infiltration first changes the water content of soil on the slope. Under the action of heavy rainfall, the soil is rapidly reached the saturated moisture content and formed a transient saturation region that penetrates to the foot of the slope under the action of hydraulic gradient and gravity. With the continuous rainfall, the transient saturation area of the slope foot and slope surface gradually expands to the interior of slope. During rainfall infiltration, the moisture content and negative pore water pressure of unsaturated soil increase gradually, which leads to a marked reduction in stromal suction. Especially in the position of the transient saturation zone, the matric suction drops to zero, and the adsorption capacity between soil particles is greatly reduced, which easily leads to slope deformation and failure. In addition, rainfall also reduces the shear strength of the soil and increases the self-weight of the slope. According to a large number of experimental studies (He et al. 2019), the internal friction and cohesion will decrease with the increase of water content. The increase of the self-weight of the slope will also promote the force of the slide. The above reasons are not conducive to the stability of the slope.

\subsection{Blasting vibration stage}

Under the influence of underwater drilling blasting, the rock mass fissure in the blasting area develops gradually and expands to the interior. It is easy to form a sliding surface when the internal cracks of the slope are accumulated and connected. However, the soil material and dynamic response of the sliding surface are often different. The physical and mechanical properties of soil decreased due to blasting vibration and repeated rubbing. When the vibration inertia force of blasting is consistent with the direction of the sliding surface, the thrust formed will promote the slope to accelerate sliding. In addition, the underwater steep slope formed by blasting excavation can also be regarded as the cutting process of the bank slope. All of them have a certain influence on the structure of the bank slope.

\subsection{Deformation and failure mechanism of the bank slope under the combined action of rainfall blasting}

The slope is in an understable state under the action of rainfall alone, and in a basically stable state under the condition of blasting vibration alone. But after coupling action, the slope is in an extremely unstable state, as shown in Fig. 13. The coupling effect is not only the superposition of the two kinds of actions but also the promotion effect of this process. Under the action of rainfall infiltration, the moisture content of unsaturated soil in slope increases greatly. Once subjected to blasting vibration, the pore water pressure of soil will increase rapidly and even produce excess pore water pressure. The excess pore water pressure superimposed with the pore water pressure accelerates the reduction of matrix suction and 
shear strength of slope. At the same time, the inertial force generated by the blasting seismic wave will increase with the increase of the slope weight under the effect of rainfall, which will weaken the stability of the slope from all aspects. In another aspect, the surface soil becomes more loosely under the blasting vibration. The soil compactness decreases and the pores between soil particles are enlarged. The blasting vibration promotes the infiltration of rainwater deeper and expands the scope of rainfall infiltration. Eventually, the bank slope accelerated to collapse and recede.

\section{Conclusion}

Using the Shaijingping landslide as an example, we analysed the failure mechanism and stability of bank slop in adjacent dredging engineering under the synergistic effect of rainfall and blasting. The following conclusion were reached:

(1) The pore water pressure variation process of continuous heavy rainfall infiltration is simulated based on the measured rainfall data. It increases with the infiltration of rainwater, while the matric suction decreases with the increase of soil water content. The overall rainfall infiltration effect decreases from the surface to the deep part of the slope. The changed water content of soil can weaken the shear strength parameters of soil and reduced the safety factor of slope.

(2) Underwater blasting excavation plays a key role in the bank collapse and failure. Under the effect of elevation amplification, the seismic wave generated by borehole blasting in deep water propagates to the top of slope through bedrock, which promotes the looseness and dispersion of shallow slope soil, increases the density between soil particles, and expands the scope of rainfall infiltration. Also, blasting vibration changes the structure form of the underwater slope bank, making the slope more vulnerable to instability and failure.

(3) This paper compares the permanent displacement of slope under the synergetic action of heavy rainfall and blasting vibration, and reveals the accelerated failure and instability mechanism of rainfallblasting bank slope.

\section{Declarations}

\section{Availability of data and material}

All data included in this study are available upon request by contacting the corresponding author.

\section{Conflicts of Interest}

The authors declare that there are no conflicts of interest regarding the publication of this paper.

\section{Funding}

This work was supported by the Chinese National Natural Science Foundation (grand no. 41672260). 


\section{References}

1. Hu XL, Tang HM, Li CD, Sun RX (2012) Stability of Huangtupo riverside slumping mass \#II under water level fluctuation of Three Gorges Reservoir. Aust J Earth Sci 23(3):326-334

2. Jiang N, Zhou CB, Lu SW (2018) Effect of Underground Mine Blast Vibrations on Overlaying Open Pit Slopes: A Case Study for Daye Iron Mine in China. Geotech Geol Eng 36(3):1475-1489

3. Kiran PA, Netra PB, Ranjan KD, Ryuichi Y (2016) Seepage and slope stability modelling of rainfallinduced slope failures in topographic hollows. Geomatics Natural Hazard Risk 7(2):721-746

4. He K, Ma GT, Hu XW, Luo G, Mei XF, Liu B, He XX (2019) Characteristics and mechanisms of coupled road and rainfall-induced landslide in Sichuan China, Geomatics. Natural Hazard Risk 10(1):23132329

5. Li DL, Liu XR, Li X, Wang (2016) The Impact of Microearthquakes Induced by Reservoir Water Level Rise on Stability of Rock Slope. Shock And Vibration. 7583108

6. Li DY, Yin KL, Leo C (2010) Analysis of Baishuihe landslide influenced by the effects of reservoir water and rainfall. Environ Earth Sci 60(4):677-687

7. Li SL, Xu Q, Tang MG, Lqbal J, Liu J, Zhu X, Liu FZ, Zhu DX (2018) Characterizing the spatial distribution and fundamental controls of landslides in the Three Gorges Reservoir area, China. Bull. Eng. Geol. Environ.

8. Li WX, Wang J, Dai LF (2006) Safety criterion of blasting shock for the high-deep slope of open-pit in mountain area. Ind Min Process 1:006. (In Chinese)

9. Liu JQ, Tang HM, Li Q, Su AJ, Liu QH, Zhong C (2018) Multi-sensor fusion of data for monitoring of Huangtupo landslide in the three Gorges Reservoir, China. Geomat Nat Haz Risk 9(1):881-891

10. Liu WP, Shi WM, Kong WX, Zheng YR (2005) Weakening effect of water on gravel-soil in Three Gorges Reservoir area, Rock and Soil Mechanics, (11):166-170. (inChinese)

11. Ma G, Hu X (2016) Stability analysis and preventive treatment measures to slope at ice water accumulation horizon in Tibet. Chin J Geol Hazard Control 27(1):38-43. https://doi.org/10.16031/j.cnki.issn.1003-8035.2016.01.07 (In Chinese)

12. Ma GT, Hu XW, Yin YP (2018) Failure mechanisms and development of catastrophic rockslides triggered by precipitation and open-pit mining in Emei, Sichuan, China. Landslides 15(7):1401-1414

13. Miao FS, Wu YP, Li LW, Tang HM, Li YN (2018) Centrifuge model test on the retrogressive landslide subjected to reservoir water level fluctuation. Eng Geol 245:169-179

14. Mikos M, Cetina M, Brilly M (2004) Hydrologic conditions responsible for triggering the Stozě landslide, Slovenia. Eng Geol 73:193-213. https://doi.org/10.1016/j.enggeo.2004.01.011

15. Panek T, Brazdill R, Klimes IJ (2011) Rainfall-induced landslide event of May 2010 in the eastern part of the Czech Republic. Landslides 8:507-516. https://doi.org/10.1007/s10346-011-0268-6

16. Song HF, Cui W (2016) A large-scale colluvial landslide caused by multiple factors: mechanism analysis and phased stabilization. Landslides 13(2):321-335 
17. Tang HM, Janusz WC, Hsei J (2019) Geohazards in the three Gorges Reservoir Area, China - Lessons learned from decades of research. Eng Geol 261:105267

18. Tang HM, Li CD, Hu XL, Wang LQ, Criss RE, Su AJ, Wu YP, Xiong CR (2015) Deformation response of the Huangtupo landslide to rainfall and the changing levels of the Three Gorges Reservoir. Bull Eng Geol Environ 74(3):933-942

19. Tang MG, Xu Q, Huang RQ (2015) Site monitoring of suction and temporary pore water pressure in an ancient landslide in the three Gorges Reservoir area, China. Environ Earth Sci 73:5601-5609

20. Wang T, Wu SR, Shi JS (2013) Case study on rapid assessment of regional seismic landslide hazard based on simplified Newmark displacement model: Wenchuan MS 8.0 Earthquake. Journal of Engineering Geology 21(1):16-24. (inChinese)

21. Wu Q, Tang HM, Ma XH, Wu YP, Hu XL, Wang LQ, Criss RE, Yuan Y, Xu YJ (2019) Identification of movement characteristics and causal factors of the Shuping landslide based on monitored displacements. Bull Eng Geol Environ 78(3):2093-2106

22. Wu TY, Zhou CB, Jiang N (2020) Stability analysis for high-steep slope subjected to repeated blasting vibration. Arab J Geosci 13(17):828

23. WU SR, SONG J, WANG T (2018) Theory and Technology of integrated prevention and control of catastrophic landslide in disturbed area of major engineering. Science Press, Beijing

24. Xu ZM, Huang RQ (2013) The assessment of the weathering intensity of Emeishan basalt based on rock blocks (i), geochemistry of weathered basalt blocks. Geol China 40(3):895-908

25. Yang BB, Yin KL, Xiao T, Chen LX, Du J (2017) Annual variation of landslide stability under the effect of water level fluctuation and rainfall in the three Gorges Reservoir, China. Environ Earth Sci 76:(564)

26. Yang ZP, Tian X, Jiang YW, Liu XR, Lai YL (2020) Experimental study on dynamic characteristics and dynamic responses of accumulation slopes under frequent microseisms. Arab J Geosci 13(16):770

27. Yin Y (2013) Investigation on catastrophic landslide of January 11, 2013 at Zhaojiagou, Zhenxiong County, Yunnan Province. J Eng Geol 21(1):6-15

28. Yin YP, Huang BL, Wang WP, Wei YJ, Ma XH, Ma F, Zhao CJ (2016) Reservoir-induced landslides and risk control in three Gorges Project on Yangtze River, China. J Rock Mech Geotech Eng 8(5):577-595

29. Zhao NH, Hu B, Yi QL, Yao WM, Ma C (2017) The coupling effect of rainfall and reservoir water level decline on the Baijiabao landslide in the Three Gorges Reservoir Area, China. Geofluids. 3724867

30. Zheng YR, Chen ZY, Wang GX, Ling TQ (2018) Engineering treatment of slope \& Landslide, Beijing, China Communications Press

\section{Figures}




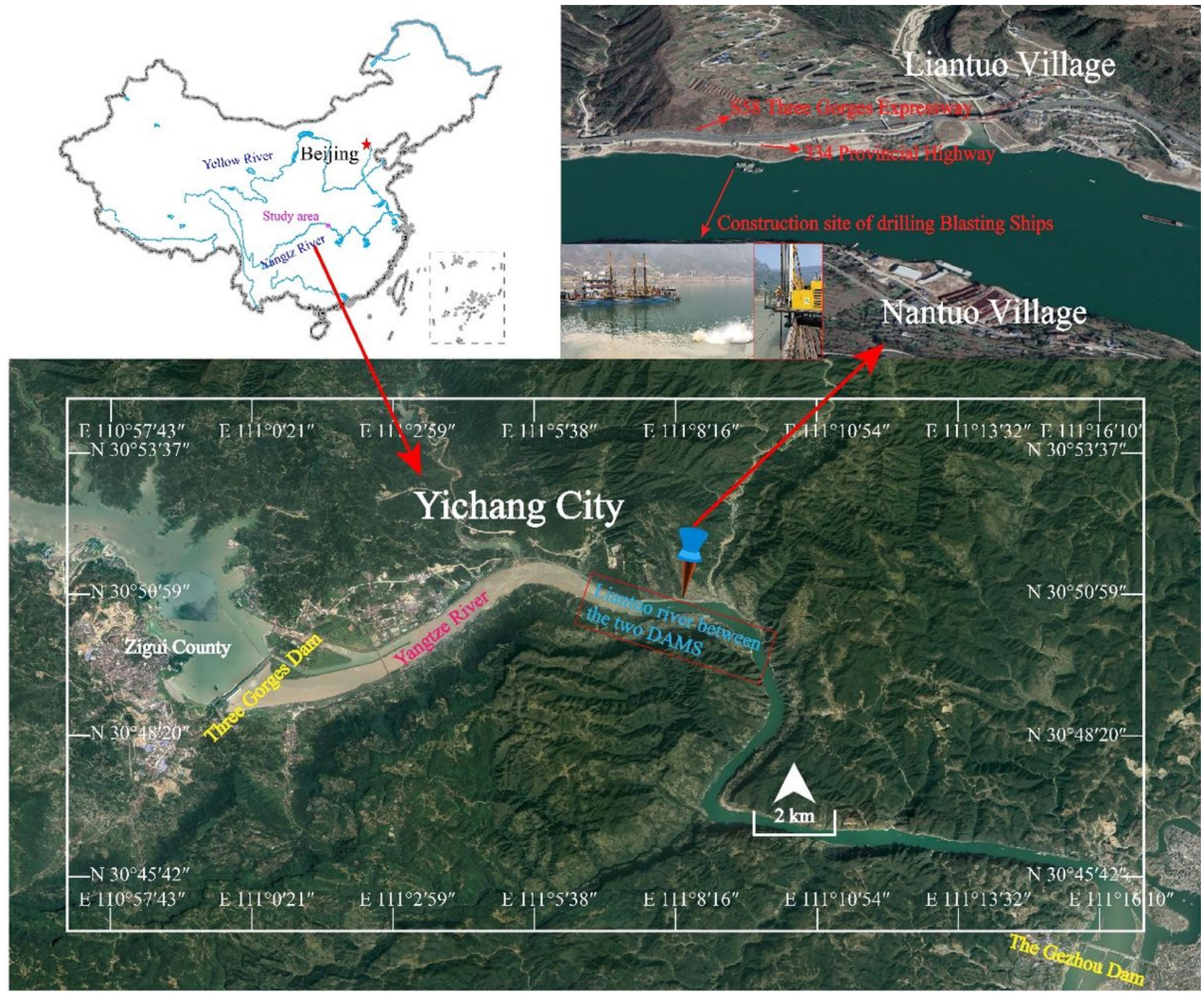

Figure 1

Location map and the underwater drilling construction area between two dams. Note: The designations employed and the presentation of the material on this map do not imply the expression of any opinion whatsoever on the part of Research Square concerning the legal status of any country, territory, city or area or of its authorities, or concerning the delimitation of its frontiers or boundaries. This map has been provided by the authors. 


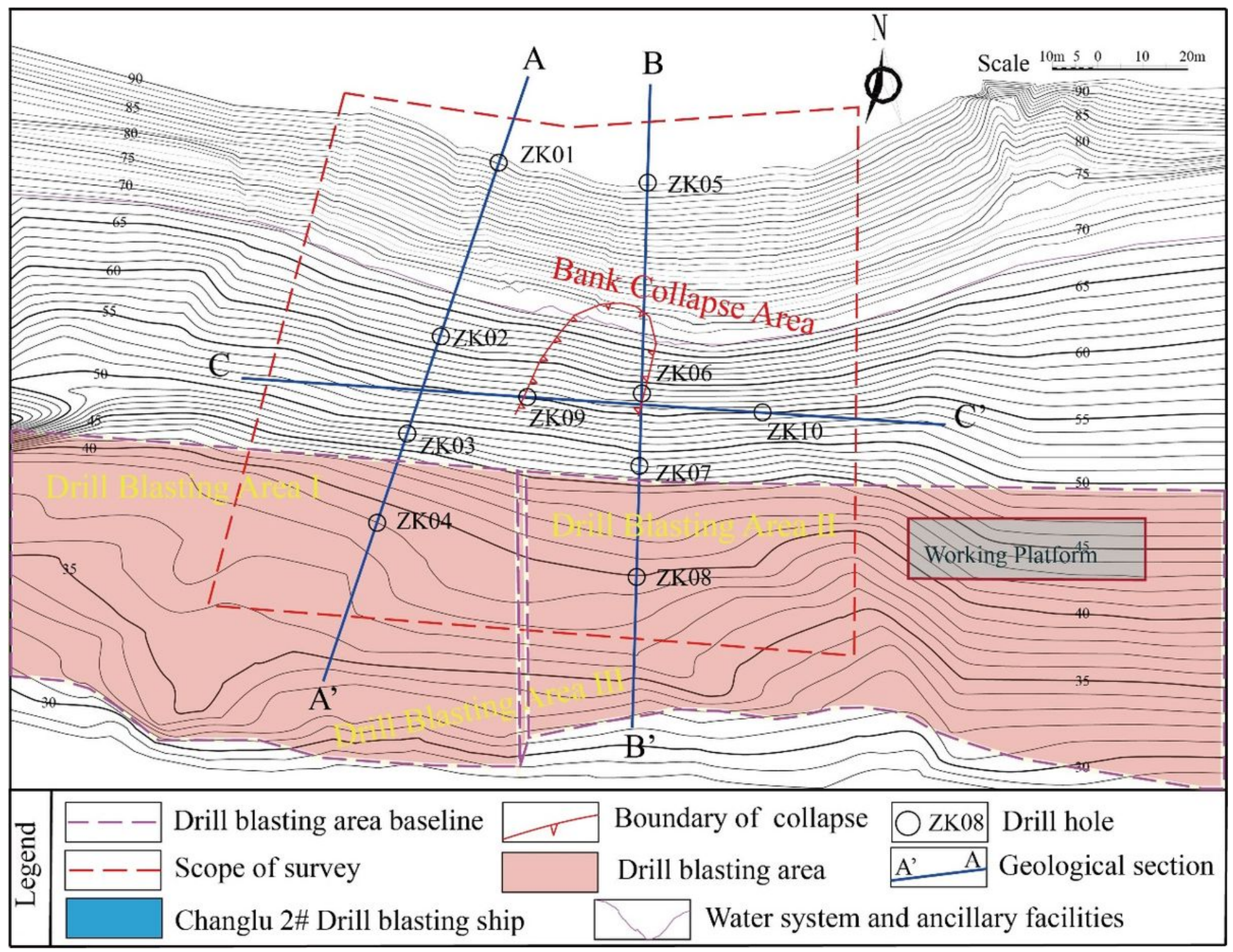

Figure 2

Overview of the Shaijingping bank slop 


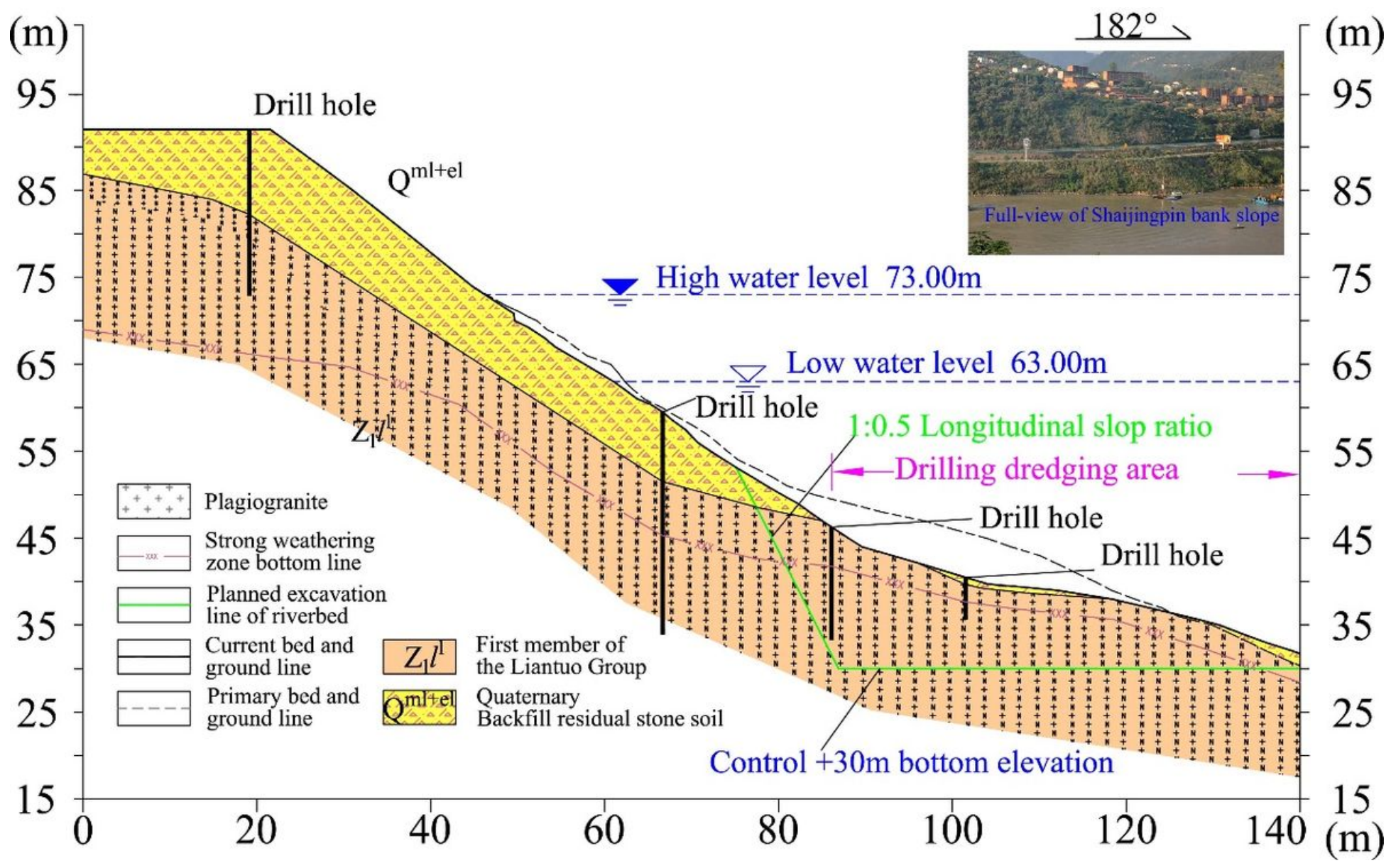

Figure 3

Typical cross-section of the Shaijingpin bank slope. 


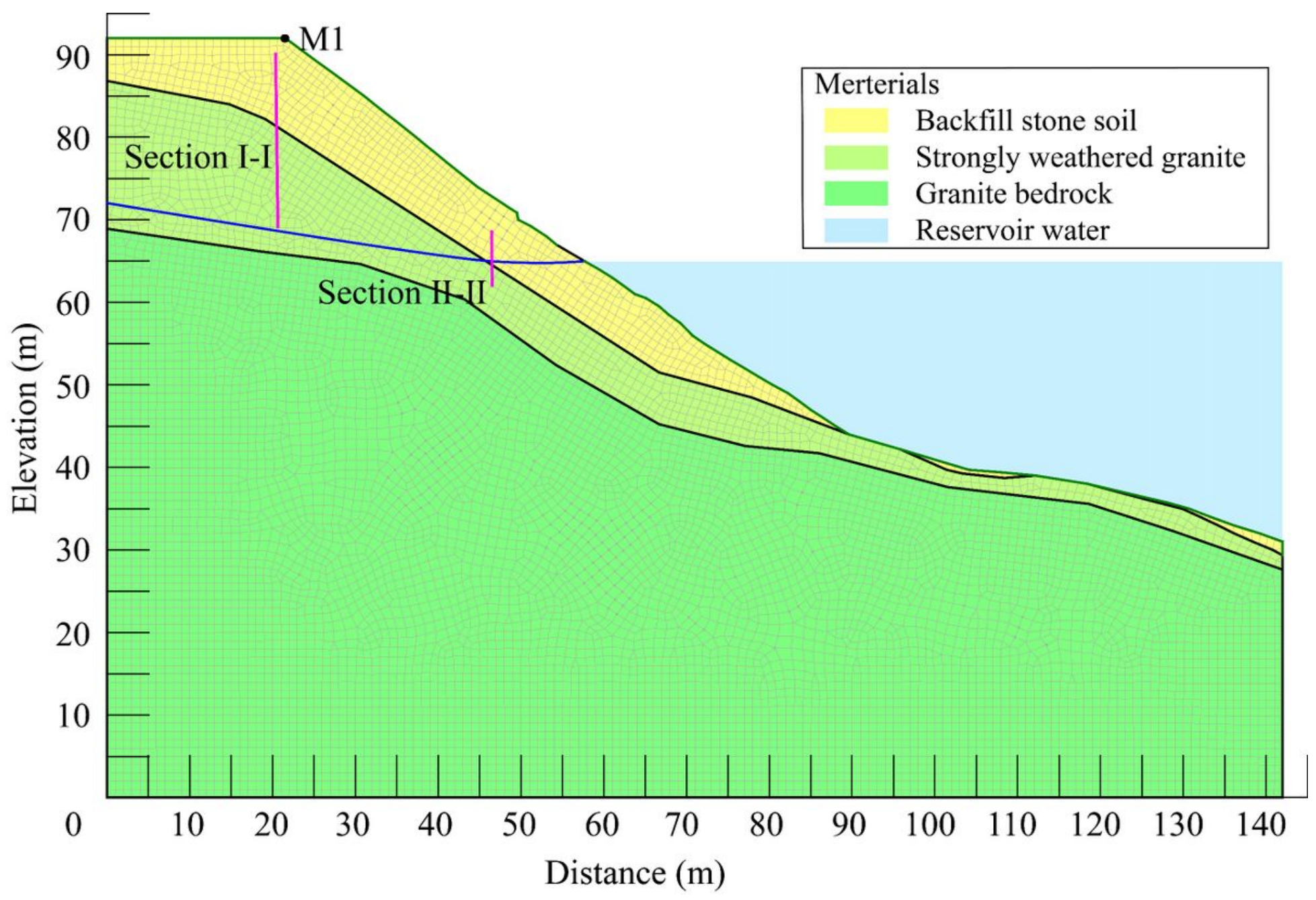

Figure 4

Numerical model of the typical cross-section of the Shaijingpin bank slope 


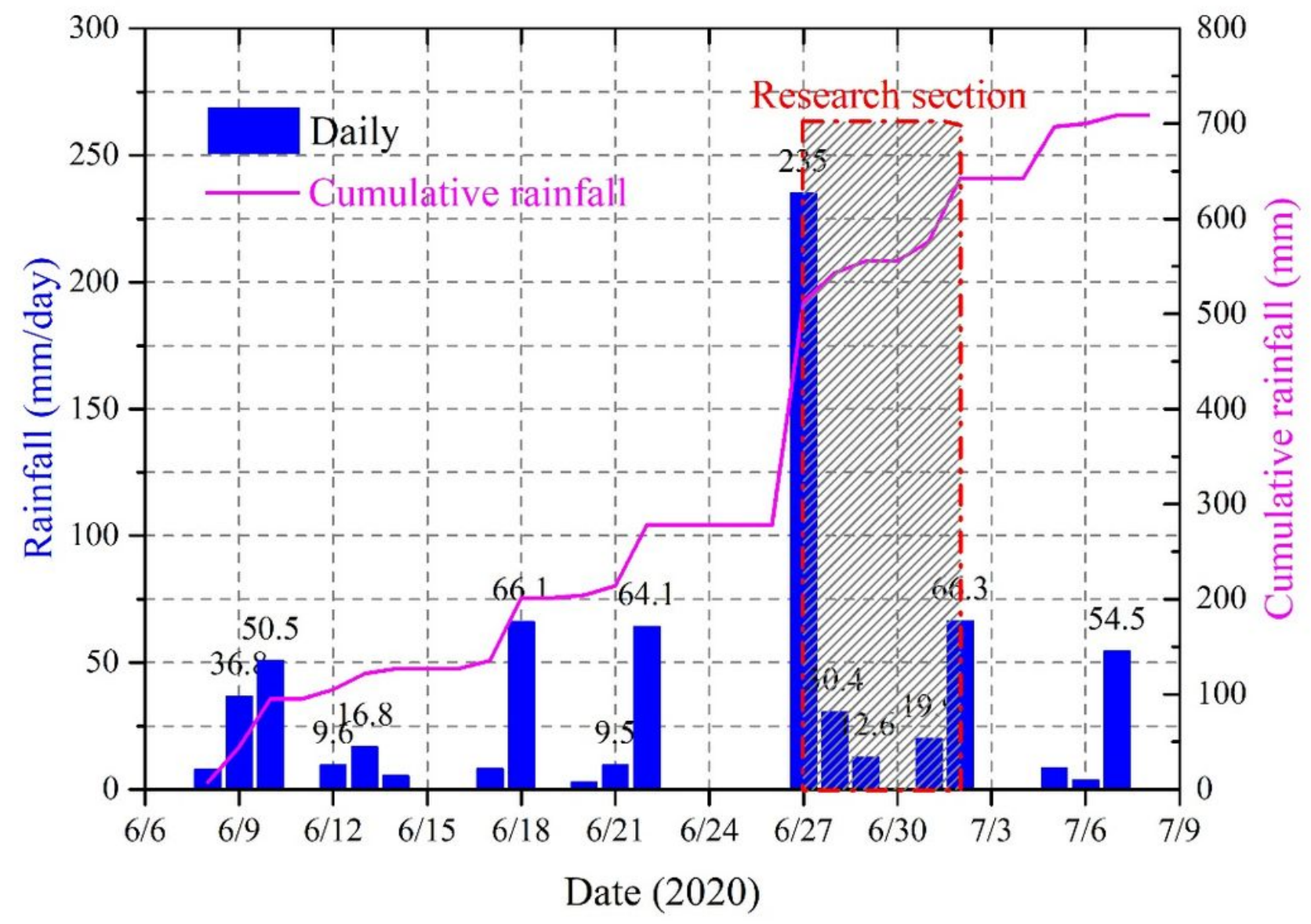

Figure 5

Daily and cumulative rainfall data of 2020 meiyu season in Yichang city 


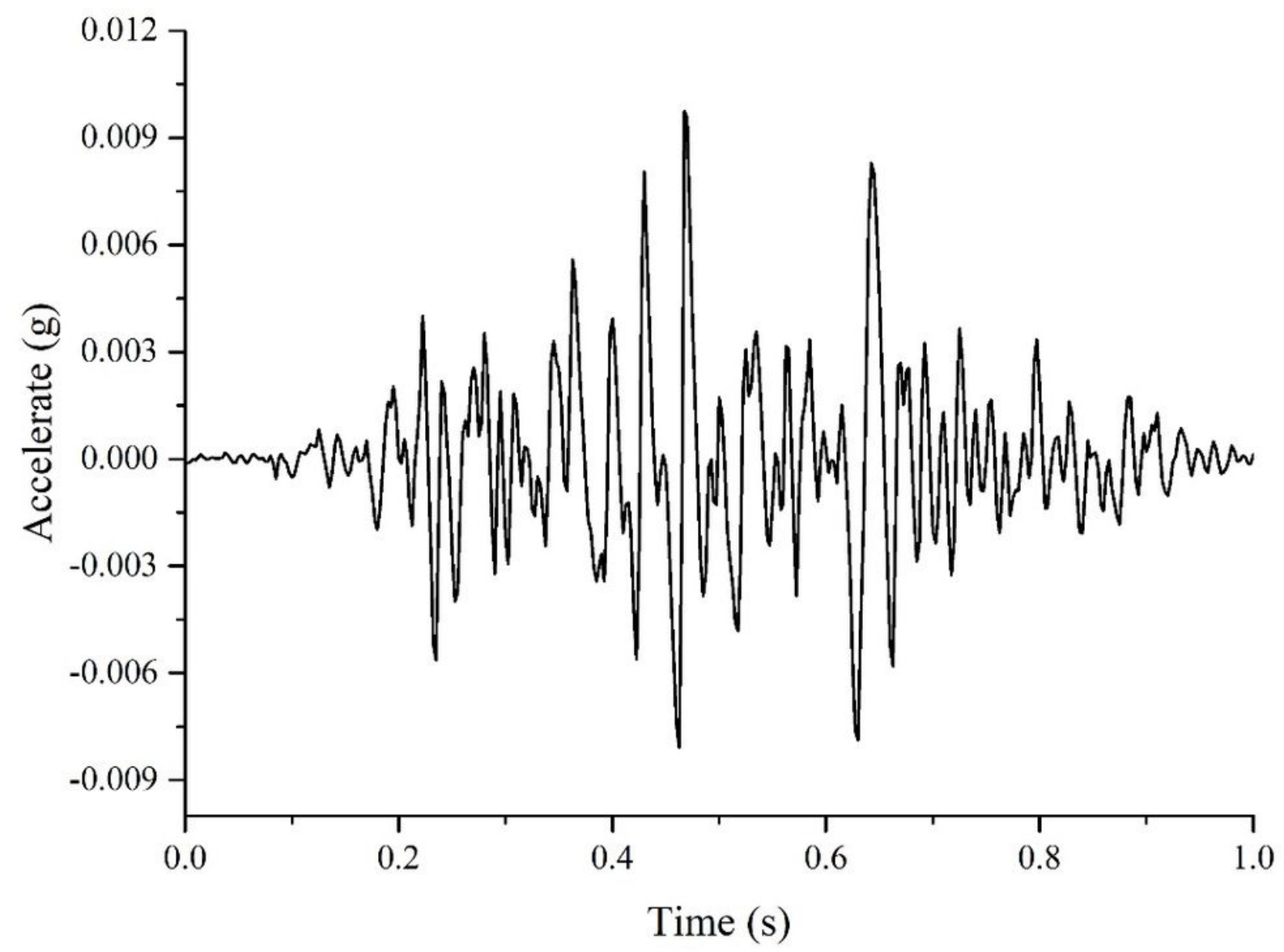

Figure 6

The time-history curve of blasting vibration acceleration of measured point in slope profile 


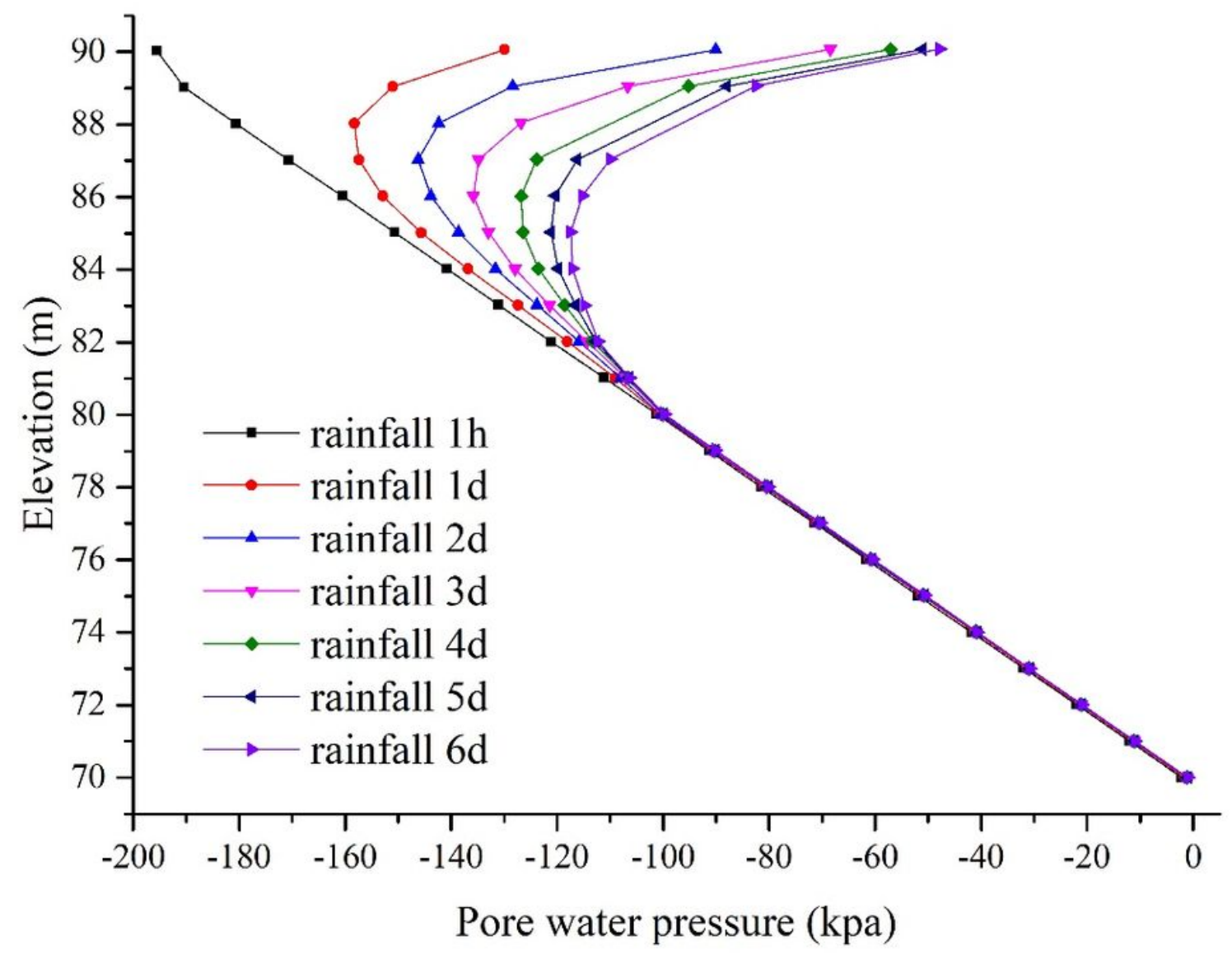

Figure 7

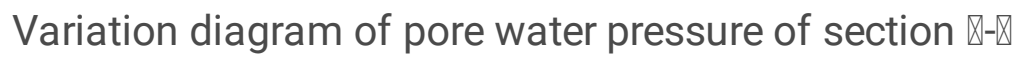




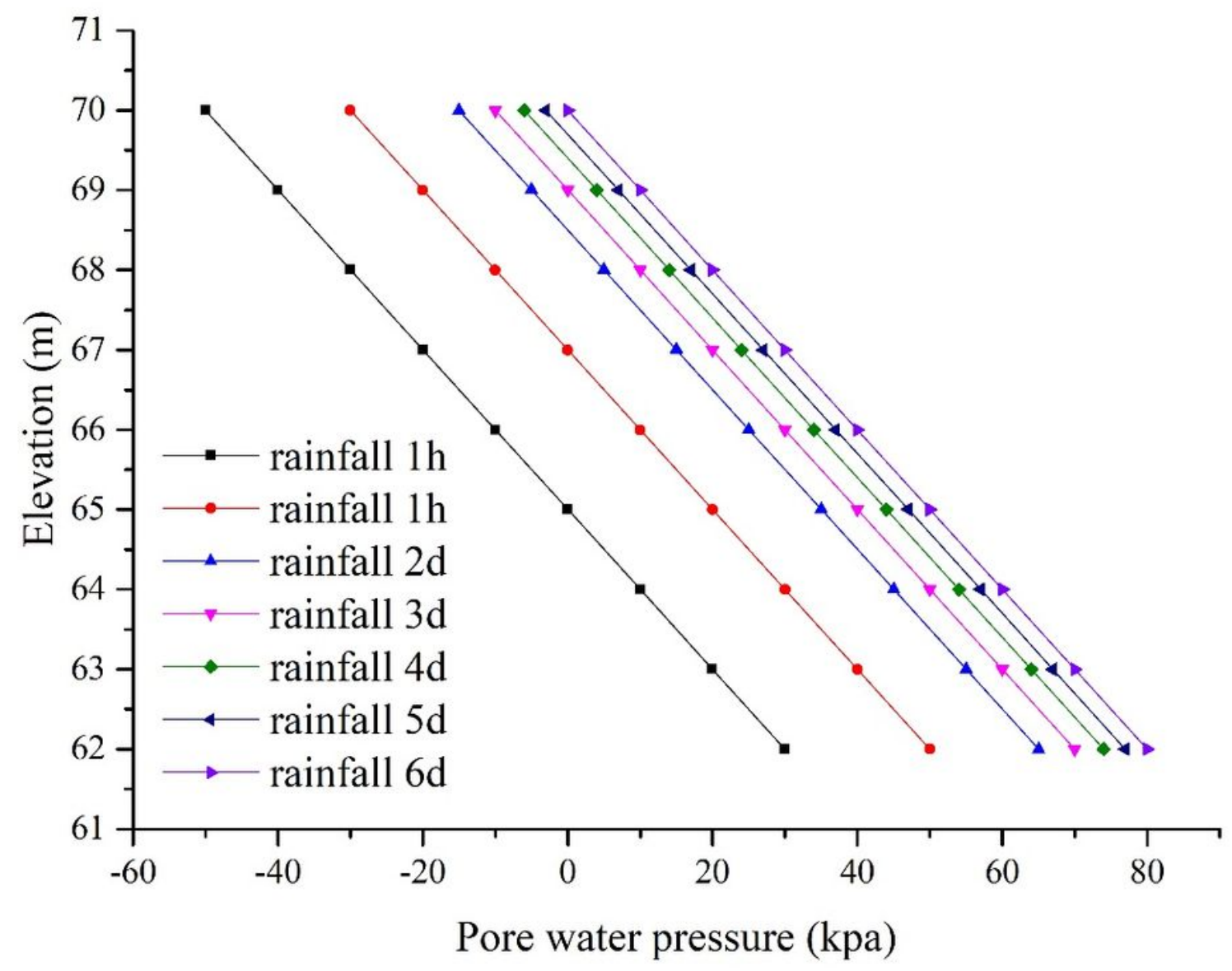

Figure 8

Variation diagram of pore water pressure of section $\mathbb{X - \bigotimes}$ 


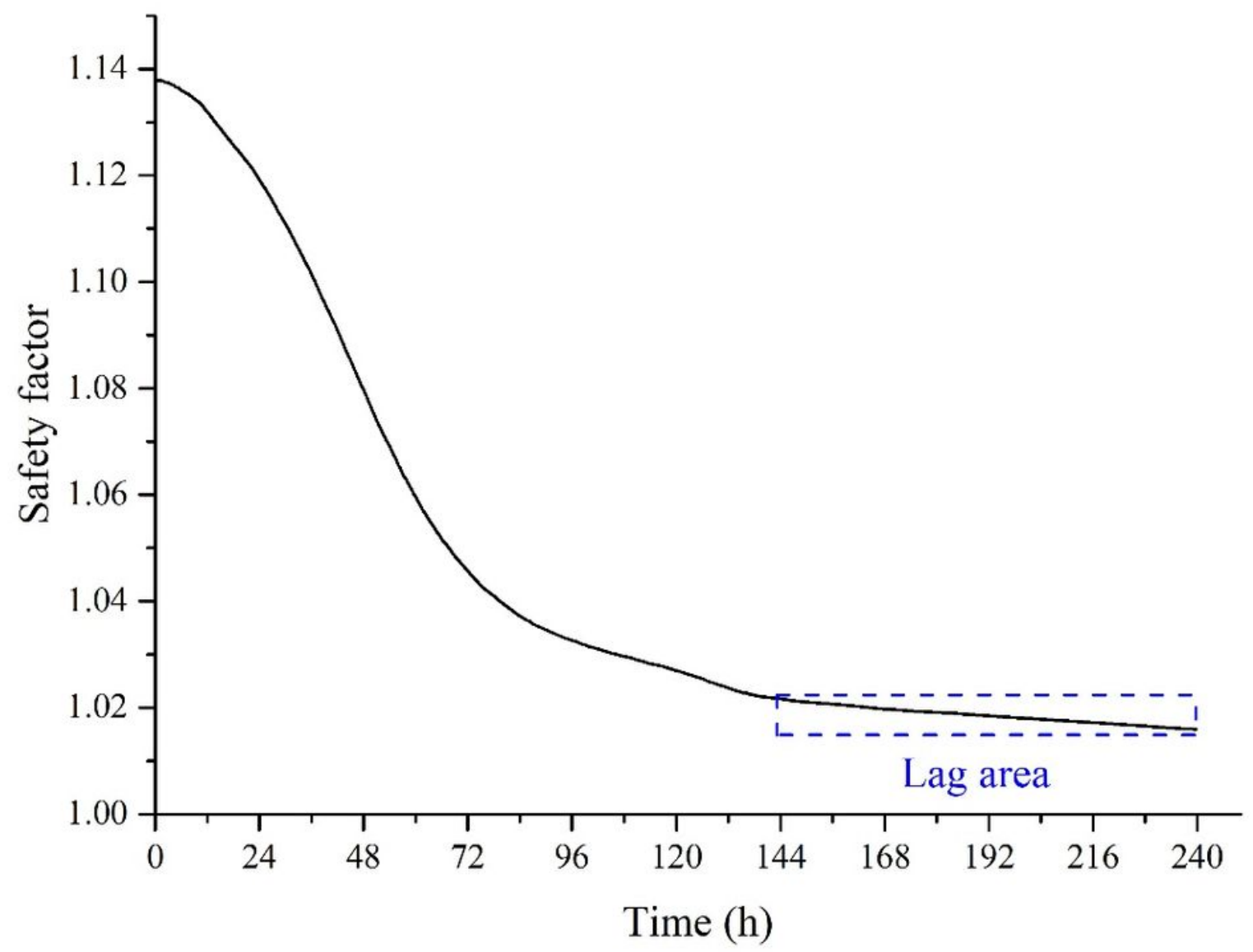

Figure 9

Curve of slope safety factor changing with time under rainfall condition 


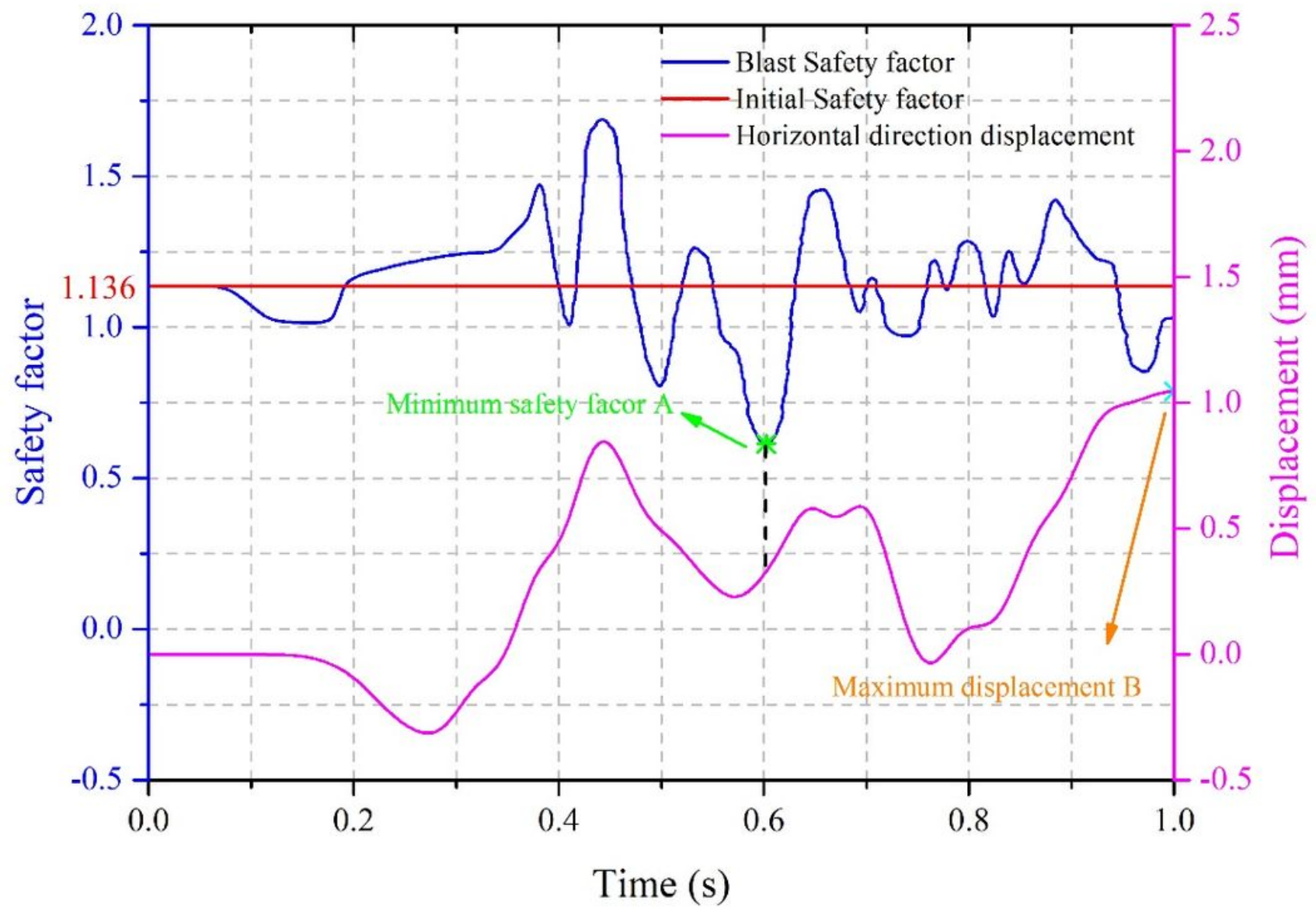

Figure 10

Safety factor changes with time and top surface monitoring point displacement map. 


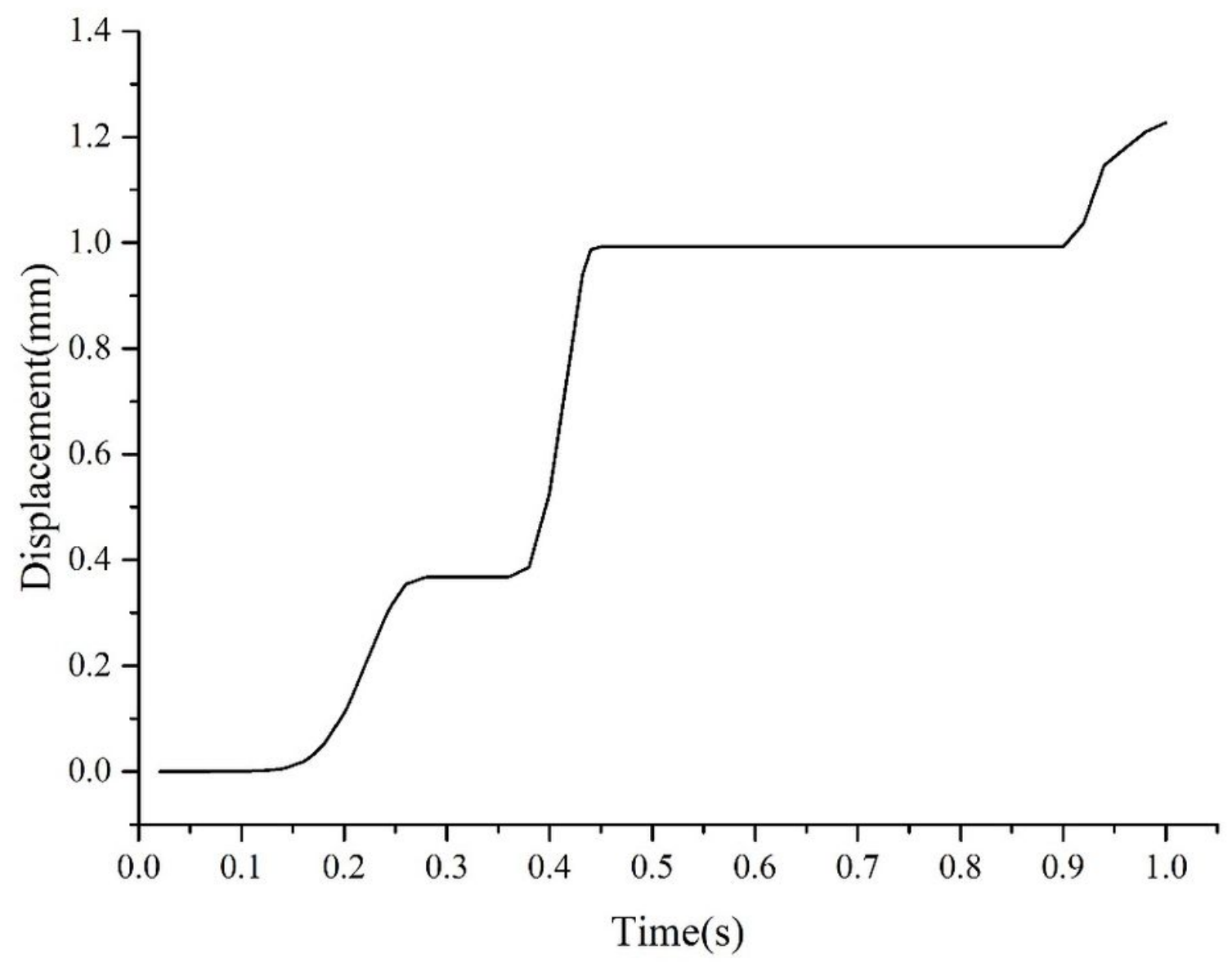

Figure 11

Permanent displacement changes with time 

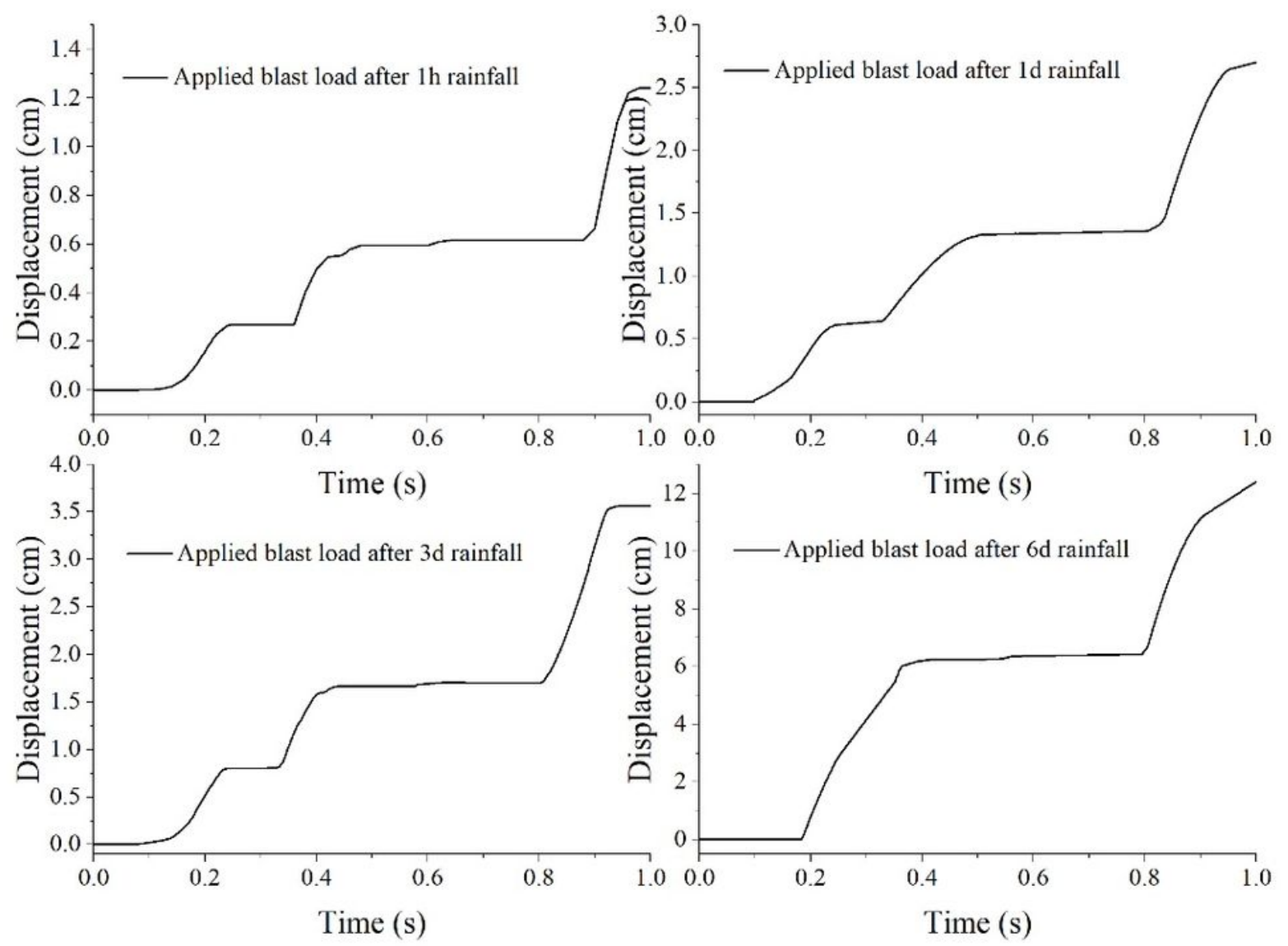

Figure 12

Permanent displacement map of blasting vibration load applied at different rainfall duration 


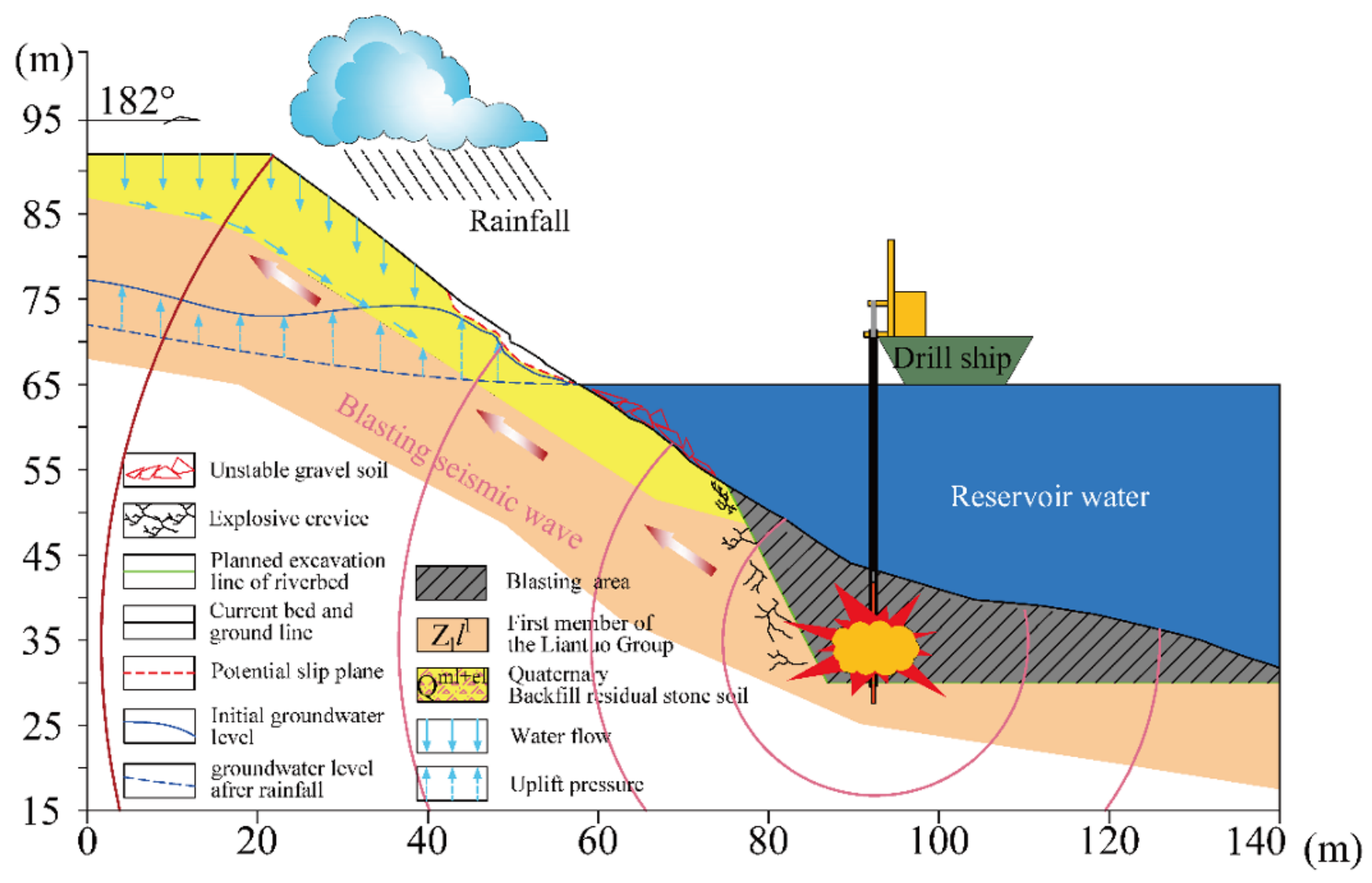

Figure 13

Formation mechanism of the Shaijingpin bank slope 